PETER BROCK is a member of the Department of History at the University of Toronto. He is the author of The Slovak National Awakening, and co-editor, with H. Gordon Skilling, of The Czech Renascence of the Nineteenth Century.

Polish populism, which advocated agrarian socialism by either revolutionary or reformist means, emerged first among the émigrés who had left Poland after the Russians defeated the nationalist uprising of 1830 . In exile they came into contact with the ideas of French 'Utopian' socialists such as Babeuf, Saint-Simon, Fourier, and Cabet, and they attempted to adapt these ideas to the very different conditions prevailing in their east European homeland. Thus this version of populism preceded in time, and probably influenced, the emergence of the ideas of the better-known Russian narodniks.

Polish Revolutionary Populism describes the activities and conflicting ideologies of the various organizations, abroad and in partitioned Poland, which were struggling for national independence and for agrarian and social reform. Like the author's recent work, The Slovak National Awakening, this book deals with the emerging national aspirations characteristic of central and eastern Europe at the time and with the variety of political and social theories that made debate so acrimonious. 
This page intentionally left blank 


\section{PETER BROCK}

\section{Polish Revolutionary Populism:}

a study in agrarian socialist thought from the 1830 s to the 1850 s

UNIVERSITY OF TORONTO PRESS 
(c) University of Toronto Press 1977

Toronto and Buffalo

Printed in Canada

Library of Congress Cataloging in Publication Data

Brock, Peter, 1920-

Polish revolutionary populism.

Bibliography: $p$.

Includes index.

1. Populism-Poland-History. 2. Socialism in

Poland-History. I. Title.

HX315.7.A6B76 $335^{\prime} .009438 \quad 77-2840$

ISBN 0-8020-5374-2

This book has been written by a member of the Centre for Russian and East European Studies, University of Toronto. A list of other books sponsored by the Centre appears at the back of the book.

This book has been published during the

Sesquicentennial year of the University of Toronto 